\title{
Gramáticas CoRporais E Políticas da ExistênCIA
}

\author{
FERREIRA, Vitor Sérgio. \\ Marcas que demarcam: tatuagem, body piercing e culturas \\ juvenis. Lisboa: Imprensa de Ciências Sociais, 2008.
}

\section{POR}

\section{Celso de Brito ${ }^{1}$}

66 Marcas que demarcam, body piercing e culturas juvenis" é resultado da tese de doutoramento de Vitor Sérgio Ferreira defendida no Instituto de Ciências Sociais da Universidade de Lisboa, em 2006. Dedicando-se a estudar questões vinculadas à juventude e ao corpo, o autor analisa, nesse livro, o sentido atribuído pela sociedade e pelos jovens portugueses ao ato de marcação corporal.

Sensível à ideia de que marcações corporais extensivas, como tatuagens e body piercing, sejam injustamente associadas a patologias psicológicas e/ ou sociais na sociedade ocidental, o autor se incumbe da tarefa de explicar sociologicamente a complexa constelação de sentidos e valores presentes em tal prática. Por trás dos sentidos e preconceitos que levam à patologização desses sujeitos existe uma "gramática de recepção", que perpetua significados historicamente estruturados e associados a um imaginário colonial, sob os quais corpos extensivamente marcados representavam figuras estigmatizadas na vida social ocidental como "selvagens", "bárbaros" e "primitivos". No entanto, há, também, uma "gramática de produção" a partir da qual é possível entender tais

\footnotetext{
${ }^{1}$ Doutorando do Programa de Pós-Graduação em Antropologia Social da Universidade Federal do Rio Grande do Sul.celsodebrito@yahoo.com.br
} 
marcações corporais como projetos identitários em plena negociação (reprodução/ reação) frente à imposição de modelos hegemonicamente padronizados da sociedade ocidental contemporânea.

De modo geral, o livro trata dessas gramáticas de produção e de recepção e do processo de construção identitária. 0 corpo, localizado entre uma e outra gramática se apresenta como uma forma de "política da existência".

No primeiro capítulo, Ferreira considera a presença de marcações corporais em diversas sociedades, apontando para a diferença significativa entre essa prática nas sociedades tradicionais - nas que se representava a pertença a um determinado grupo e a submissão do indivíduo perante os valores coletivos - e nas sociedades ocidentais - nas que tal prática, popularizada a partir do século XVIII, torna-se um distintivo de "selvageria" e "desvio de personalidade", adquirindo, ao longo tempo, características que designam individualidade. Disso decorre a persistência do lugar marginal que as tatuagens e o body piercing ainda ocupam no imaginário social da sociedade ocidental contemporânea, mesmo depois de haver sido incorporados pela moda e adentrado em alguns circuitos de classes dominantes.

No capítulo seguinte, Ferreira faz uma distinção entre duas modalidades de consumo das marcas corporais: a realização de uma marca no corpo como adorno e a realização de muitas tatuagens ou body piercings pelo corpo todo. A primeira se refere a uma experiência momentânea e inaugural relacionada à moda, que pode vir a se desenvolver para a segunda e se tornar um projeto identitário longo e duradouro.

A passagem da "encarnação experiencial", da feitura da primeira marcação para a "encarnação projetual”, é considerada por Ferreira, no capítulo 3. Na "encarnaç̧ão projetual", jovens de diferentes classes, gêneros e etnias constroem suas identidades subjetivas e mais perenes. Entretanto, apesar desse caráter individual da prática de marcação corporal extensiva, evidencia-se uma aura coletiva através da partilha de um mesmo princípio orientador: os jovens que se dedicam às tatuagens e body piercing pelo corpo todo são baseados em uma "estética como ideal ético caracterizado pela divergência frente aos modelos juvenis de corporeidade dominantes" (p. 99).

No capítulo 4, Ferreira se refere à pele como o órgão do corpo mais social entre todos os outros órgãos, no sentido de que é através dele que o indivíduo se relaciona com o mundo. Assim, o ato de marcar o corpo extensivamente representa um esforço do indivíduo em alterar a sua pele e, por extensão, a sua relação com o mundo. 
As marcas que são escolhidas para alterar a relação dos indivíduos com 0 mundo obedecem a uma lógica autobiográfica. Elas representam acontecimentos de crise e metamorfose pessoal que, ao longo do acumulo de marcações, transformam o corpo no suporte de uma identidade singular e duradoura. Tratase de um ritual que serve como elemento mnemônico, marcador de mudanças pessoais, ao mesmo tempo em que oferece um símbolo de continuidade da personalidade, já que a "encarnação projetual" se refere a uma postura de rebeldia que passa a ser indelével. Mais que um "ritual de passagem", Ferreira diz se tratar de um "ritual de impasse" que expressa uma forma criativa de mudança na continuidade, propiciando aos jovens portugueses, em última instância, um "bem-estar identitário".

No capítulo 5, Ferreira analisa os sentidos políticos da prática de marcação corporal. 0 autor percebe que os jovens, desencantados com as instâncias políticas tradicionais, constroem sociabilidades participativas e exercem protagonismo social através de códigos próprios para manifestar opiniões e aspirações sobre 0 mundo. Essas ações sociais e políticas têm no corpo o seu maior instrumento de manifestação, já que o corpo é a única instância percebida pelos jovens portugueses estudados como passível de possibilitar uma sensação de empoderamento. Imbuídos de uma sensação de poder que o ato de exercer posse sobre o próprio corpo lhes fornece, os jovens se impõem simbolicamente em relação à sociedade de controle que confere tal poder apenas para instituições legitimadas como a ciência médica, a escola e a família.

Essa divergência simbólica não se expressa apenas pela esfera imagética. Os jovens portugueses analisados pelo autor também se expressam através de discursos de oposição às organizações sociais e relações de poder específicas descritas por eles mesmos como "sociedade de consumo", "sistema capitalista" e "tecnocracia", a mesmo tempo em que enaltecem sistemas organizacionais alternativos à sociedade ocidental, referindo-se a "organizações holistas" de "sociedades tribais" e "sociedades primitivas".

Esse modo de fazer política se distancia tanto da política formal quanto das "políticas de emancipação" que caracterizaram os movimentos sociais da década de 60 e 80. Trata-se, segundo Ferreira de "política de vida" que visa alargar as condições de exercício das decisões de vida, pretendendo conquistar, não o poder político formal, mas espaços de manobra para novas formas de protagonismo que permitam a auto-realização identitária, apontando, assim, para uma "ética de pluralismo co-existencial" (p. 213). 
No último capítulo, Ferreira busca entender os contornos entre "nós" e "os outros" da sociabilidade dos sujeitos inseridos em projetos de marcação corporal extensiva, assim como a distância entre a "gramática de produção" e a "gramática de recepção".

Referente ao "nós" dos jovens portugueses, cujos corpos são extensivamente marcados, segundo Ferreira, não se pode definir em termos de um "nós associativo", como descrito por trabalhos anteriores, nos quais se atribuíam às tatuagens e ao body piercing's elementos representativos de pertencimentos a "tribos urbanas". 0 termo proposto pelo autor, para se referir às outras formas de organização social que ele encontrou nos casos analisados, é o de "nós sociativo", formado temporariamente com base em afetividades e afinidades pontuais, que não exige semelhança entre pares, mas sim reconhecimento e respeito às diferenças partilhadas, diferenças que encontram unidade a partir do momento em que são consideradas "alternativas".

Essa cumplicidade circunstancial entre diferentes jovens de corpos extensivamente marcados se materializa em locais de sociabilidades específicos como encontros e mostras de profissionais de tatuagens e body piercing, concertos musicais ou eventos de motoqueiros. Ferreira afirma que esses encontros são importantes por produzirem uma sensação de normalidade - diferente de normatividade, na medida em que não se conforma às normas dominantes da prática entre os próprios jovens, pois possibilita um ambiente propício para a vivência de jovens extensivamente marcados sem o peso do "estigma" de uma prática ainda patologizada e sancionada socialmente.

Fora desses "espaços sociativos", os corpos extensivamente marcados permanecem sendo corpos sob suspeita e "estigma", gerando a necessidade de uma gestão social e cálculo dos riscos envolvidos no projeto de marcação corporal extensiva, já que os sujeitos mantêm uma relação ativa com o mercado de trabalho e a família. Eles analisam tanto o local a ser preservado (rosto e mãos, principalmente), quanto como e de quem esconder as marcas.

Enfim, Sérgio Vitor Ferreira nos apresenta um livro instigante na medida em que consegue conduzir o leitor, por meio de uma rica etnografia, por entre os caminhos tortuosos e contraditórios de um processo de construção de identidades juvenis na sociedade ocidental contemporânea, demonstrando os pontos de determinação estrutural e de autonomia com os quais se deparam os jovens adeptos das marcações corporais extensivas, assim como apresenta uma discussão fértil relativa ao alargamento do conceito tradicional de política. 